\title{
KARAKTERISTIK DAN KUANTIFIKASI BENTUK PENGELOLAAN SAMPAH PERUMAHAN
}

\author{
Putu Indra Christiawan $^{1)^{*}}$ dan Sutarjo ${ }^{1)}$ \\ 1) Universitas Pendidikan Ganesha, Singaraja \\ ${ }^{*}$ Email : indra.christiawan@undiksha.ac.id
}

\begin{abstract}
Abstrak
Kelurahan Banyuning merupakan bagian dari wilayah Kota Singaraja yang potensial mengalami masalah sampah perumahan. Kenyataan ini didukung dengan keberadaan kompleks perumahan sebagai penggunaan lahan terbesar di Kelurahan Banyuning. Keberadaan kompleks perumahan secara tidak langsung berkontribusi besar terhadap besaran timbulan sampah dan variasi komposisi sampah yang dihasilkan. Berdasarkan dari fenomena tersebut, kajian ini memiliki tujuan untuk: (1) menganalisis karakteristik sampah perumahan dan (2) menganalisis bentuk pengelolaan sampah perumahan.. Metode yang digunakan dalam pencapaian tujuan penelitian ini adalah survei analitik dengan populasi adalah pemukim kompleks perumahan. Penelitian survei analitik ini menggunakan sampel area dengan teknik purposive sampling, dan menggunakan teknik proportional random sampling untuk mengambil sample subjek. Analisis yang digunakan dalam penelitian ini adalah statistik deskriptif dan statistik inferensial. Penelitian ini memberikan gambaran mengenai eksistensi pengelolaan sampah yang diproduksi oleh pemukim kompleks perumahan yang bervariasi berdasarkan besaran timbulan sampah dan jenis komposisi sampah.
\end{abstract}

Kata-Kata Kunci: Sampah, Perumahan, Pengelolaan Sampah

\begin{abstract}
Banyuning Sub-district is part of the Singaraja City area which is potential to experience the problem of housing waste. This fact is supported by the existence of housing complex as the largest land use in Banyuning Sub-district. The existence of residential complexes indirectly contribute greatly to the amount of waste generation and variation of the composition of waste generated. Based on the phenomenon, this study aims to: (1) analyze the characteristics of housing waste and (2) analyze the form of waste management of housing. The method used in the achievement of the purpose of this study is an analytical survey with the population is residential complex housing. This analytical survey research uses area samples with purposive sampling technique, and using proportional random sampling technique to take sample subjects. The analysis used in this research is descriptive statistics and inferential statistics. This study provides an overview of the existence of waste management produced by residential complex housing that varies based on the amount of waste generation and the type of garbage composition.
\end{abstract}

Keywords: Waste, Housing, Waste Management 


\section{PENDAHULUAN}

Kota merupakan wilayah yang mengalami pertumbuhan penduduk sangat masif. Pertumbuhan penduduk kota yang besar memiliki konsekuensi terhadap kebutuhan ruang hidup yang besar. Ruang sebagai wadah yang dibutuhkan penduduk kota untuk bertempat tinggal secara konvensional dibedakan menjadi permukiman pribadi dan umum. Berdasarkan pada UU No. 1 Tahun 2011 tentang Perumahan dan Kawasan Permukiman, perumahan didefiniskan sebagai kumpulan rumah sebagai bagian dari permukiman, baik perkotaan maupun perdesaan, yang dilengkapi dengan prasarana, sarana, dan utilitas umum sebagai hasil upaya pemenuhan rumah yang layak huni. Kompleks perumahan di wilayah kota secara umum ditujukan bagi penduduk pendatang. Dengan kata lain, pemukim pada kompleks perumahan adalah bersifat heterogen.

Salah satu heterogenitas ini dapat dilihat dari segi pekerjaan. Pekerjaan sebagian besar pemukim di kompleks perumahan adalah bergerak pada sektor industri dan jasa, sehingga kompleks perumahan yang dibangun di wilayah kota memiliki sifat perkotaan. Di sisi lain, kompleks perumahan adalah salah satu lahan terbangun (builtup area) perkotaan yang memiliki tekanan yang tinggi terhadap daya dukung lingkungan. Degradasi lingkungan kompleks perumahan sebagai salah satu masalah ekologi kota merupakan manifestasi dari tekanan pemukim yang melampaui daya dukung lingkungan kompleks perumahan.

Sampah merupakan faktor determinan dalam permasalahan ekologi kota, khususnya pada lingkungan perumahan. Pemukim kompleks perumahan yang bersifat perkotaan adalah produsen sampah perumahan terbesar. Dengan kata lain, sampah perumaham yang dihasilkan oleh pemukim kompleks perumahan bersifat sampah perkotaan. Sampah perkotaan yang dikenal dengan istilah municipal solid waste (MSW) adalah sampah rumah tangga perkotaan yang terdiri dari barang-barang sehari-hari seperti kemasan produk, potongan rumput, furnitur, pakaian, botol, sisa makanan, surat kabar, peralatan dan baterai (Guerrero, Maas, \& Hogland, 2013). Sejalan dengan batasan tersebut, dalam PP No. 81 Tahun 2012 tentang Pengelolaan Sampah Rumah Tangga dan Sampah Sejenis Sampah Rumah Tangga dijelaskan bahwa sampah rumah tangga adalah sampah yang berasal dari kegiatan rumah tangga sehari-hari. Berdasarkan kedua batasan tersebut, sampah perkotaan adalah sampah yang bersifat limbah padat hasil dari aktivitas permukiman.

Kota Singaraja adalah ibukota Kabupaten Buleleng Provinsi Bali yang memiliki permasalahan ekologi kota yang juga bersumber dari sampah perumaha. Keberadaan sampah 
perkotaan tidak terlepas dari karakteristik Kota Singaraja sebagai kota pendidikan. Predikat sebagai kota pendidikan mengakibatkan jumlah penduduk Kota Singaraja mengalami pertambahan yang signifikan. Pertambahan penduduk tersebut didominasi penduduk pendatang dari luar kota, baik sebagai mahasiswa maupun sebagai tenaga pendidik dan tenaga pegawai. Pertambahan penduduk Kota Singaraja sebagai konsekuensi kota pendidikan mengakibatkan peningkatan kebutuhan ruang tempat tinggal. Pembangunan kompleks perumahan merupakan salah satu wadah yang mengakomodasi peningkatan kebutuhan akan ruang tempat tinggal bagi penduduk pendatang di Kota Singaraja.

\section{Kelurahan Banyuning} merupakan kelurahan di Kota Singaraja dengan luas wilayah, jumlah penduduk dan kompleks perumahan serta angka timbulan sampah terbesar. Kelurahan Banyuning memiliki luas wilayah $5,13 \mathrm{~km}^{2}$ atau $18,39 \%$ dari total luas wilayah Kota Singaraja dan jumlah penduduk sebesar 16.057 jiwa atau $16,66 \%$ dari total penduduk Kota Singaraja pada tahun 2014 (BPS Kab. Buleleng, 2015). Berdasarkan data Kantor Pelayanan Terpadu tentang Daftar Perumahan Umum dan Perumahan BTN, bahwa dari 16 kompleks perumahan yang terdapat di Kota Singaraja 8 diantaranya tersebar di wilayah Kelurahan Banyuning. Di sisi lain, berdasarkan data Dinas Kebersihan dan Pertamanan menyatakan bahwa Kelurahan Banyuning adalah wilayah dengan potensi timbulan sampah rumah tangga terbesar, yaitu $32,51 \mathrm{~m}^{3} /$ hari dari total 89,06 $\mathrm{m}^{3}$ /hari di Kota Singaraja. Kenyataan ini mengungkapkan bahwa sebagai wilayah dengan sebaran komplek perumahan terbanyak, Kelurahan Banyuning adalah penghasil sampah rumah tangga terbesar di Kota Singaraja. Eksisting dari sebaran kompleks perumahan dan besaran timbulan sampah pada masing-masing kelurahan yang memiliki kompleks perumahan di Kota Singaraja seperti terlihat pada Tabel 1.

Tabel 1. Korelasi Kompleks Perumahan dengan Timbulan Sampah

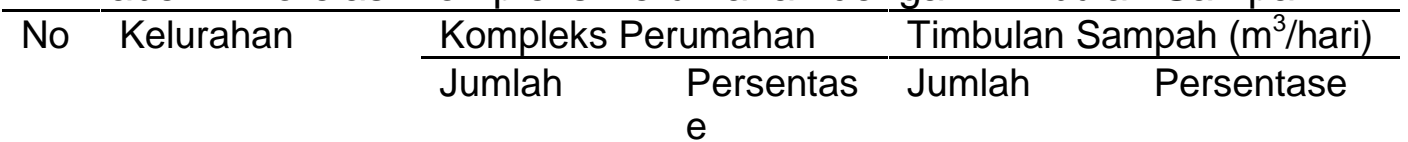

(1) (2)

1 Baktiseraga

2 Banyuasri

3 Paket Agung

4 Banyuning

5 Penarukan Total
(3)

4

2

1

8

1

16
(4)

25

12,5

6,25

50

6,25

100
(5)

10,32

15,70

4,89

32,51

25,64 89,06
(6)

11,59

17,63

5,49

36,50

29,91 100

Sumber: Diolah dari Data Kantor Pelayanan Terpadu dan Dinas Kebersihan dan Pertamanan Kabupaten Buleleng Tahun 2014 
Berdasarkan data pada Tabel 1 terlihat bahwa masalah sampah perkotaan sangat berkaitan dengan keberadaan kompleks perumahan. Keterkaitan ini terdapat di Kelurahan Banyuning sebagai bagian dari wilayah kota yang memiliki kompleks perumahan terbanyak, sekaligus sebagai wilayah dengan timbulan sampah terbesar di Kota Singaraja. Fenomena timbulan sampah pada kompleks perumahan ini merupakan manifestasi dari permasalahan pengelolaan sampah.

Permasalahan

pengelolaan sampah ini memiliki dampak negatif yang kompleks. Dampak negatif langsung dari pengelolaan sampah yang tidak baik meliputi penurunan kualitas dan kesehatan lingkungan yang diakibatkan berbagai zat pencemar, serta kenyamanan lingkungan yang diakibatkan bau tidak sedap dan polusi visualisasi (Budihardjo, 2014). Dampak negatif permasalahan pengelolaan sampah perkotaan ini dalam jangka panjang akan mengakibatkan wajah Kota Singaraja pada umumnya, dan Kelurahan Banyuning pada khususnya menjadi kumuh (slums). Permasalahan pengelolaan sampah perumahan ini merupakan awal dari krisis ekologi kota yang bermuara pada suatu bencana perkotaan (urban disaster). Pengkajian secara mendalam mengenai pengelolaan sampah perumahan bersifat urgen. Urgenitas kajian ini diperlukan untuk menentukan langkah atau kebijakan untuk pengelolaan sampah perumahan secara holistik dan berjangka panjang. Berdasarkan urgenitas kebutuhan tersebut, maka dipandang penting untuk mengkaji bentuk pengelolaan sampah perumahan.

\section{METODE}

Pendekatan dalam penelitian ini menggunakan kombinasi pendekatan kuantitatif dan kualitatif. Kombinasi pendekatan kuantitatif dan kuantitatif dalam penelitian ini adalah dengan perpaduan pendekatan kuantitatif digunakan untuk memfasilitasi pendekatan kualitatif. Pendekatan kuantitatif dalam penelitian ini bertujuan untuk menguji hipotesis dan menunjukkan hubungan antarvariabel serta memberikan deskripsi statistik, sedangkan pendekatan kualitatif bertujuan untuk mengembangkan pengertian dan konsep-konsep dari variabel penelitian yang pada akhirnya menjadi teori baru.

Rancangan dalam penelitian ini menggunakan rancangan penelitian survei analitik. Survei analitik yang mencoba menggali tentang proses sebab akibat dari fenomena yang terjadi (Notoatmodjo, 2002). Dalam penelitian survei analitik ini, penelitian tidak dilakukan terhadap seluruh populasi yang diteliti, tetapi hanya mengambil sebagian dari populasi tersebut. Rancangan penelitian survei analitik yang digunakan adalah cross sectional dengan melakukan pengukuran variabel 
bebas terhadap variabel terikat yang diukur dan dikumpulkan secara simultan. Adapun objek dalam penelitian ini adalah karakteristik sampah dan pengelolaan sampah perumahan, sedangkan subjek penelitian adalah pemukim kompleks perumahan.

Data dalam penelitian terdiri dari data primer dan data sekunder. Data primer meliputi data: (1) karakteristik sampah yang meliputi timbulan dan komposisi sampah dan (2) pengelolaan sampah perumahan yang dikumpulkan secara langsung dari sumber asli atau objek maupun subjek penelitian. Sedangkan yang termasuk ke dalam data sekunder meliputi data: (1) jumlah kompleks perumahan, dan (2) jumlah kepala keluarga (KK) kompleks perumahan yang bersumber dari instansi Kantor Kelurahan Banyuning.

Analisis data merupakan tahapan kegiatan dalam mengolah data penelitian yang terkumpul untuk kemudian diinterpretasikan sebagai berikut.

Analisis data pertama yang dilaksanakan adalah analisis kuantitatif yang bersifat deduktif untuk menguji hipotesis penelitian. Data yang dianalisis adalah data yang berasal dari instrumen yang telah melalui uji validitas dan reliabilitas. Analisis kuantitatif yang digunakan adalah statistik deskriptif dan statistik inferensial. Statistik deskriptif yang digunakan adalah tabel frekuensi untuk mendeskripsikan data yang terkumpul tanpa uji signifikansi, sedangkan statistik inferensial yang digunakan adalah regresi linear berganda untuk menguji taraf signifikansi hipotesis yang diajukan. Analisis ini digunakan untuk mengetahui arah hubungan, baik positif maupun negatif antara variabel bebas karakteristik sampah dengan variabel terikat pengelolaan sampah perumahan, dan untuk memprediksi nilai dari variabel terikat apabila nilai variabel bebas mengalami kenaikan atau penurunan.

Analisis kualitatif yang dilaksanakan setelah analisis kuantitatif bersifat induktif untuk menghasilkan sintesis dari hubungan karakteristik sampah dengan pengelolaan sampah perumahan. Analisis kualitatif diawali dengan mengatur, mengurutkan, mengelompokkan dan mengkategorikan data, sheingga diperoleh temuan berdasarkan pertanyaan penelitian yang telah diajukan.

\section{HASIL DAN PEMBAHASAN}

\section{Karakteristik Sampah Perumahan di Kelurahan Banyuning}

Karakteristik Timbulan Sampah

Timbulan sampah adalah sejumlah sampah yang dihasilkan oleh suatu aktivitas dalam kurun waktu tertentu, atau dengan kata lain banyaknya sampah yang dihasilkan dalam satuan berat (kilogram) gravimetri atau volume (liter) volumetri. Menurut Damanhuri dan Padmi (2010), prakiraan timbulan sampah baik untuk saat sekarang maupun di masa mendatang merupakan 
dasar dari perencanaan, perancangan, dan pengkajian sistem pengelolaan persampahan. Satuan timbulan sampah ini secara umum dinyatakan sebagai satuan skala kuantitas per orang atau per unit bangunan. Skala kuantitas tersebut antara lain adalah satuan timbulan sampah dalam: (1) satuan berat, yaitu kilogram per orang perhari (kg/orang/hari) dan (2) satuan volume, yaitu liter per orang perhari (liter/orang/hari).

Timbulan sampah
merupakan ukuran kuantitatif dari keberadaan sampah. Dalam penelitian ini satuan ukuran timbulan sampah direpresentasi berdasarkan satuan berat, yaitu kilogram per orang per hari ( $\mathrm{kg} /$ orang/hari) selama 8 hari pada lokasi yang sama untuk menggambarkan kondisi sampah rumah tangga harian kompleks perumahan. (Pitoyo, 2003) mengungkapkan bahwa timbulan sampah sangat dipengaruhi oleh tingkat pendapatan dan pola konsumtif, selain jumlah penduduk. Adapun karakteristik timbulan sampah perumahan di Kelurahan Banyuning seperti terlihat pada Tabel 2.

Tabel 2. Karakteristik Timbulan Sampah Perumahan di Kelurahan Banyuning

\begin{tabular}{llll}
\hline No & Timbulan Sampah & $\mathrm{F}$ & $\%$ \\
\hline 1 & Kurang dari $2 \mathrm{Kg}$ & 40 & 40 \\
2 & $2 \mathrm{Kg}$ s.d $4 \mathrm{Kg}$ & 45 & 45 \\
3 & Lebih dari $4 \mathrm{Kg}$ & 15 & 15 \\
& Total & 100 & 100 \\
\hline
\end{tabular}

Sumber: Analisis Data Primer, 2017

Karakteristik timbulan sampah perumahan di Kelurahan Banyuning menunjukkan bahwa timbulan sampah yang mendominasi adalah pada interval $2 \mathrm{Kg}$ sampai dengan $4 \mathrm{Kg}$ yang berjumlah 45 rumah tangga atau sebesar 45\%. Kondisi menunjukkan bahwa sampah yang dihasilkan rumah tangga pemukim perumahan Kelurahan Banyuning relatif tinggi. Sampah yang dihasilkan pemukim secara langsung mengurangi daya dukung tempat penampungan sementara (TPS) dalam menampung sampah yang dihasilkan pemukim. Daya dukung TPS yang sudah melampaui batas ditandai dengan: (1) sampah yang meluber hingga di luar TPS, (2) menimbulkan aroma busuk dari sampah yang menumpuk, (3) menjadi tempat hidup berbagai vektor penyakit dan (4) menurunkan kualitas dari lingkungan perumahan.

Timbulan sampah pada tempat pembuangan sampah sementara akan menghasilkan lindi. Leachate/lindi adalah limbah cair yang timbul akibat masuknya air eksternal ke dalam timbunan sampah, melarutkan dan membilas materi-materi terlarut, 
termasuk juga materi organik hasil proses dekomposisi biologis. Kuantitas dan kualitas lindi akan sangat bervariasi dan berfluktuasi. Leachate atau lindi yang tidak ditangani dengan baik yaitu tanpa melalui pengolahan dapat memberikan dampak negatif pada lingkungan di sekitar tempat penampungan sampah sementara antara lain timbulnya bau sehingga mengurangi estetika, timbulnya penyakit karena leachate/lindi merupakan sarang atau tempat vector (pembawa) penyakit (Sukrorini, Budiastuti, Ramelan, \& Kafiar, 2014). Vektor atau pembawa penyakit yang ditimbulkan dari tempat sampah adalah thypus, disentri dengan vector pembawa penyakit adalah lalat, kecoa, tikus dan lain sebagainya. Lindi yang timbul di TSP akan mencemari lingkungan sekitar, baik berupa rembesan dari dasar TPS yang mencemari air tanah di bawahnya, maupun pada lahan yang terletak di kemiringan. Kecepatan aliran air tanah akan cukup tinggi sehingga dimungkinkan terjadi cemaran terhadap sumur penduduk yang terletak pada elevasi yang lebih rendah. Di sisi lain, rumah yang berlokasi di sekitar TPS akan terganggu akan aroma tidak sedap akibat dari keberadaan lindi tersebut, terutama pada saat musim hujan.

Karakteristik Komposisi Sampah
Damanhuri dan Padmi
(2010) menyatakan bahwa
sampah dapat dikelompokkan
berdasarkan komposisinya, misalnya dinyatakan sebagai \% berat (biasanya berat basah) atau \% volume (basah) dari kertas, kayu, kulit, karet, plastik, logam, kaca, kain, makanan, dan lainlain. Komposisi sampah tersebut digolongkan ke dalam 2 komponen utama sampah yang terdiri dari: (1) sampah organik yang meliputi sisa makanan, kertas, karbon, plastik, karet, kain, kulit, kayu dan (2) sampah anorganik yang meliputi kaca, alumunium, kaleng, logam, abu dan debu.

Suarna

menyebutkan

(2008)

sampah berdasarkan sifat fisik dan kimianya menjadi: 1) sampah ada yang mudah membusuk terdiri atas sampah organik seperti sisa sayuran, sisa daging, daun dan lain-lain; 2) sampah yang tidak mudah membusuk seperti plastik, kertas, karet, logam, sisa bahan bangunan dan lain-lain; 3) sampah yang berupa debu/abu; dan 4) sampah yang berbahaya (B3) bagi kesehatan, seperti sampah berasal dari industri dan rumah sakit yang mengandung zat-zat kimia dan agen penyakit yang berbahaya. Adapun karakteristik komposisi sampah perumahan di Kelurahan Banyuning seperti terlihat pada Tabel 3. 
Tabel 3. Karakteristik Komposisi Sampah Perumahan di Kelurahan Banyuning

\begin{tabular}{llll}
\hline No & Komposisi Sampah & $\mathrm{F}$ & $\%$ \\
\hline 1 & Lebih besar Sampah Organik & 4 & 4 \\
2 & Seimbang antara Sampah Organik dan & 0 & 0 \\
& $\begin{array}{l}\text { Anorganik } \\
3\end{array}$ & & \\
& Lebih besar Sampah Anorganik & 96 & 96 \\
& Total & 100 & 100 \\
\hline
\end{tabular}

Sumber: Analisis Data Primer, 2017

Karakteristik komposisi sampah perumahan di Kelurahan Banyuning menunjukkan bahwa sebagian besar sampah yang dihasilkan pemukim adalah sampah anorganik sebesar $96 \%$. Sampah anorganik yang dihasilkan pemukim adalah: (1) sampah plastik berupa kantong plastik, botol plastik dan kemasan makanan ringan, (2) alat tulis kantor berupa kertas, alat tulis dan (3) alat dan bahan bangunan berupa sisa-sisa konstruksi bangunan. Sampah anorganik adalah sampah yang paling banyak dihasilkan, dan paling tidak mudah diurai secara alami. Secara teknis sampah anorganik di definisikan sebagai limbah yang tidak dapat atau sulit terurai atau busuk secara alami oleh miro organism pengurai sebab unsur karbonnya memebentuk rantai kimia yang kompleks dan panjang (Hasibuan, 2016). Keberadaan sampah anorganik ini diprediksi akan berdampak kepada lingkungan geofisik, biotis dan sosial ekonomi budaya dan kesehatan masyarakat (Sukrorini et al., 2014).

\section{Pengelolaan Perumahan Banyuning}

Pengelolaan sampah merupakan rangakaian kegiatan yang bertujuan untuk meningkatkan kesehatan masyarakat dan kualitas lingkungan serta menjadikan sampah sebagai sumberdaya. Dari sudut pandang kesehatan lingkungan, pengelolaan sampah dipandang baik jika sampah tersebut tidak menjadi media berkembang biaknya bibit penyakit serta sampah tersebut tidak menjadi medium perantara menyebarluasnya suatu penyakit. Secara garis besar, kegiatan di dalam pengelolaan sampah meliputi pengendalian timbulan sampah, pengumpulan sampah, transfer dan transportasi dan pembuangan akhir (Kartikawan, 2007).

Secara
pengelolaan sampah dapat
dibedakan ke dalam $3 \mathrm{R}$, yaitu
reduce, reuse dan recycle.
Sadoko (1993) mengemukakan konsep 3R sebagai berikut. Pertama, reduce adalah metode pengelolaan dengan mengurangi volume sampah. Kegiatan ini disebut juga tindakan pencegahan sampah, dilakukan dengan cara mengonsumsi barang lebih sedikit dan tidak banyak menggunakan kemasan. Pada umumnya kemasan yang 
lebih besar menghasilkan sampah lebih sedikit dibandingkan dengan kemasan yang lebih kecil dan memiliki kecenderungan sekali pakai. Kedua, reuse adalah salah satu teknik pengolahan menggunakan barang kembali yang telah dipakai tanpa melalui proses pengubahan. Barang yang tidak dapat digunakan lagi dapat disumbangkan kepada orang lain atau menjualnya. Ketiga, recycle adalah salah satu teknik pengolahan mendaur ulang barang yang tidak terpakai dengan malalui sesuatu proses, misalnya kertas daur ulang yang diperoleh dari kertas-kertas bekas.

\begin{tabular}{llr}
\multicolumn{2}{c}{ Pengelolaan } & sampah \\
merupakan & suatu & upaya \\
penanganan & sampah & untuk
\end{tabular}
penanganan sampah untuk mengurangi jumlah dan dampak negatif dari keberadaan sampah. Dalam penelitian ini satuan ukuran pengelolaan sampah direpresentasi ke dalam bentuk mereduksi sampah (reduce), pemanfaatan kembali (reuse), dan daur ulang (recycle). Reduce atau mengurangi sampah dapat dilakukan dengan cara: (1) menggunakan bahan atau barang yang awet, (2) mengurangi penggunaan barang sekali pakai, (3) mengurangi belanja barang yang tidak terlalu dibutukan, (4) merawat dan memperbaiki pakaian, mainan, perkakas dan peralatan rumah tangga daripada menggantinya dengan yang baru,
(5) menggunakan kantong plastik (kresek) 3 sampai 5 kali untuk berbelanja dan (6) menggunakan keranjang atau kantong yang dapat digunakan berulang ulang. Reuse dapat dilaksanakan dengan pemakaian kembali barang bekas tanpa harus memprosesnya dulu antara lain: (1) menggunakan kembali kemasan untuk fungsi yang sama atau fungsi lainya, (2) memanfaatkan barang kemasan menjadi tempat penyimpanan sesuatu diantaranya kertas bekas, botol plastik, botol kaca masih dapat dipergunakan kembali untuk keperluan lainnya, sampah kertas dan koran bekas dapat digunakan kembali sebagai pembungkus barang-barang, botol plastik digunakan sebagai tempat bibit tanaman, (3) menggunakan bahan yang bisa dipakai ulang daripada yang sekali buang, yaitu dengan membeli batere yang dapat diisi ulang daripada batere sekali buang. Recycle adalah dengan upaya mendaur ulang barangbarang yang sudah tidak berguna lagi, dan atau dikirimkan ke industri formal yang memanfaatkan sampah menjadi barang lain. Aswadi dan Hendra (2011) mengungkapkan bahwa pengelolaan sampah dipengaruhi oleh karakteristik sampah. Adapun bentuk pengelolaan sampah perumahan di Kelurahan Banyuning seperti terlihat pada Tabel 4. 
Tabel 4. Pengelolaan Sampah Perumahan di Kelurahan Banyuning

\begin{tabular}{llll}
\hline No & Pengelolaan Sampah & $F$ & $\%$ \\
\hline 1 & Reduce & 30 & 30 \\
2 & Reuse & 51 & 51 \\
3 & Recycle & 19 & 19 \\
& Total & 100 & 100 \\
\hline
\end{tabular}

Sumber: Analisis Data Primer, 2017

Berdasarkan Tabel 4 tampak bahwa bentuk pengelolaan sampah perumahan yang mendominasi adalah reuse sebesar 51\%. Reuse atau penggunaan kembali sampah yang dihasilkan, terutama sampah anorganik berupa botol plastik, kaleng cat dan kertas. Botol plastik banyak digunakan kembali sebagai media untuk menanam tanaman dan sebagai tempat detergen atau alat kebersihan lain. Kaleng cat selain digunakan sebagai media tanam, banyak juga digunakan kembali sebagai tempat perlengkapan alat kerja kantor dan juga sebagai alat olahraga. Kertas bekas atau kertas yang sudah dicetak dapat digunakan kembali dengan memanfaatkan sisi yang belum dicetak. Dengan kata lain, sampah anorganik yang dihasilkan paling besar oleh pemukim perumahan dikelola dengan bentuk reuse.

Selain ketiga bentuk pengelolaan sampah tersebut, pemukim juga mengelola sampah dengan cara membakar sampah. Sampah yang dibakar mayoritas adalah sampah dedaunan dan juga sampah kertas. Kebiasaan membakar sampah secara bebas memang sudah membudaya di masyarakat. Kebiasaan membakar sampah ini sudah membudaya sehingga sangat sulit untuk menghentikannya. Mereka belum menyadari bahwa jenis sampah saat ini berbeda dengan sampah jaman dulu. Apabila sampah-sampah tersebut dibakar maka akan mengeluarkan gas-gas beracun yang dapat membahayakan kesehatan masyarakat yang menghirupnya dan memperburuk kualitas lingkungan udara. Di sisi lain, jarak antara bangunan rumah yang dekat akan mengganggu kenyamanan tetangga.

\section{PENUTUP}

$\begin{array}{llr} & \text { Berdasarkan hasil analisis } \\ \text { dan interpretasi r data } & \text { dan } \\ \text { menunjukkan bahwa terdapat } \\ \text { rangkaian pola keberadaan } \\ \text { sampah perumahan yang } \\ \text { bertautan dengan upaya } \\ \text { pemukim dalam mengelola } \\ \text { sampah yang dihasilkan. } \\ \text { Pemukim perumahan yang }\end{array}$
bersifat heterogen menghasilkan timbulan sampah yang bervariasi. Timbulan sampah yang dihasilkan sebesar $2 \mathrm{Kg}$ sampai dengan $4 \mathrm{Kg}$ didominasi oleh jenis sampah anorganik. Dalam mengelola sampah anorganik yang dihasilkan, sebagian besar pemukim mengambil bentuk pengelolaan reuse atau mengelola sampah dengan 
menggunakannya kembali untuk kebutuhan tertentu. Akan tetapi, sampah anorganik yang dikelola dengan bentuk reuse juga memiliki waktu guna yang terbatas, terutama sampah yang digunakan kembali secara temporer sebagai media atau wadah perlengkapan tertentu. Produk reuse yang sudah rusak tidak akan dapat digunakan kembali, dan pada akhirnya akan menjadi sampah. Maka dari itu, diperlukan peningkatan bentuk pengelolaan sampah anorganik menjadi bentuk recycle atau mendaur ulang sampah menjadi produk berbeda dengan penggunaan yang lebih optimal, lebih tahan lama dan lebih kreatif serta bernilai ekonomis. Dalam mewujudkan gagasan tersebut, dibutuhkan peran para akademisi untuk memberikan pembinaan, dan peran pemerintah untuk memfasilitasi kegiatan tersebut, sehingga sampah anorganik yang dihasilkan dapat didaur ulang (recycle) untuk digunakan kembali (reuse) dan mengurangi (reduce) konsumsi produk yang dapat dihasilkan dari pengelolaan sampah anorganik yang dihasilkan pemukim perumahan di Kelurahan Banyuning.

\section{DAFTAR PUSTAKA}

Aswadi, M., \& Hendra. (2011). Perencanaan pengelolaan sampah di perumahan tavanjuka mas. Mektek, 13(2), 99-110.

Badan Pusat Statistik Kabupaten Buleleng. (2015). Kabupaten Buleleng Dalam Angka
Tahun 2015.

Budihardjo, E. (2014). Reformasi Perkotaan: Mencegah

Wilayah Urban Menjadi "Human Zoo." Jakarta: Kompas.

Damanhuri, E., \& Padmi, T. (2010). Pengelolaan Sampah. Bandung: ITB.

Guerrero, L. A., Maas, G., \& Hogland, W. (2013). Solid waste management challenges for cities in developing countries. Waste Management, 33(1), 220232.

Hasibuan, R. (2016). Analisis Dampak Limbah/Sampah Rumah Tangga Terhadap Pencemaran Lingkungan Hidup. Jurnal IImiah Advokasi, 4(1), 42-52.

Kartikawan, Y. (2007). Pengelolaan Persampahan. Yogyakarta: Andi.

Notoatmodjo, S. (2002). Metodologi Penelitian Kesehatan. Jakarta: Rineka Cipta.

Pitoyo, C. (2003). Studi Komposisi Sampah Perkotaan Pada Tingkat Rumah Tangga di kota Depok. Universitas Gunadarma.

Sadoko, K. (1993). Timbulan, Komposisi dan Karakteristik Sampah. Padang: Universitas Andalas.

Suarna, I. W. (2008). Model Penanggulangan Masalah Sampah Perkotaan dan Perdesaan. In Seminar dan Lokakarya Dies Natalis UNUD ke-46 Universitas Udayana. 
Sukrorini, T., Budiastuti, S., Ramelan, A. H., \& Kafiar, F. P. (2014). Kajian dampak timbunan sampah terhadap lingkungan di tempat pembuangan akhir (TPA) putri cempo surakarta. Jurnal Ekosains, 6(3), 56-70. 